\title{
In the Shadow of the Serbian Paramilitary Units: Narrative Patterns about the Role of Paramilitary Units in Former Yugoslav Conflict
}

\author{
Maria Vivod \\ Laboratory "Cultures and Societies of Europe", Strasbourg, France \\ Email:vivod@hotmail.com
}

Received October $16^{\text {th }}, 2012$; revised November $17^{\text {th }}, 2012$; accepted December $12^{\text {th }}, 2012$

\begin{abstract}
This article ${ }^{1}$ offers several basic data about Serbian paramilitary units employed in the armed conflict of the 1990's during the decomposition of the former Yugoslavia, with the goal to depict the transformation of the representation of the paramilitary unit members and their leaders essentially through Serbian media. Once, at the beginning of the conflicts, represented as the "saviors", "protectors" of the Serbian nation, ever present as main figures of the public life of the 90's - they have fallen into oblivion after a decade. Their most notorious leaders are either dead or in prison. After the fall of the Milošević regime (2000) their involvement in war crimes, looting and genocide reached Serbia. From being divinized gradually they become diabolized. The contemporary events and happenings in Serbia are explained in the light of the past of these paramilitary units.
\end{abstract}

Keywords: Paramilitary; Serbia; War Crimes; Genocide; Former Yugoslavia; Veterans

\section{Introduction}

The fieldwork for this paper was done in the period 20052010. Statements and press releases of public personages (politicians, journalists, artists, etc.) which appeared during that period in the local media and on the web portals of independent media about several events on the political scene in Serbia were collected and analyzed in an ethnographic manner, in comparison and in the prism of the past events and media releases during the time of the Milošević era.

In a relatively short period of time - a decade and in some cases even less (the last conflict of the Yugoslav federation decomposition was in 1999) - the "guys" from various paramilitary units which were abundantly covered in the local media of the 90's turned from "good ones" into "bad ones". After providing several basic data about the Serbian paramilitary units, the article examines the shift of narrative patterns (public opinion, labeling, metaphors) on these units. Seen as heroes, amply exploited in the Milošević-era media during the years of the conflict of former Yugoslavia, a decade after the conflict they have fallen into oblivion: only few cases were prosecuted in the mean-time for war-crimes and they sole existence and the actual role they played in various war crimes and genocide still uncovered to the Serbian public, they became a synecdoche of the Milošević-era.

The ambition of the article is to analyze the shift in the pattern of labeling and national imagery of this group of individuals: in the first stance the story about the Serbian paramilitaries falls into a line of debate about how images from the national history, in the Serbian case, from the epic songs and stories are

\footnotetext{
${ }^{1}$ This article is partially based on a lecture given in Leiden, Holland at the Ethnografeast IV

http://www.socialsciences.leiden.edu/anthropology/research/ethnografeastiv/ ethnografeastiv/about.html.
}

become visible and exploited during national mobilization. I argue that the actual settings of wartime which largely contributed to the exploitation of national and epic imagery also contributed to their downfall in peacetime for an obvious reason among others: the strived goal-victory and conquest of "Serbian territories" - was not attained. In the process of "de-armament" strictu sensu of the political currents in Serbia and deagitation after a decade of war-cycles which goal was to "maintain the unity of the Serbian nation" the stories about these paramilitary units, former heroes of the nation became "unusable" elements in the narratives about the Serbian nation and the Serbian state.

\section{Theoretical Background}

Already at the beginning of the 90's Ivan Colović, a Serbian ethnologist who analyzed press articles and its relation to the Serbian folklore and in this manner marvelously dissect the Serbian society at the time of fervent nationalism of the Milošević-era put in the pivotal place, among the "Serbian constellation of narratives" or narrative leitmotifs the narratives about the "Serbian warrior and hero" (Čolović, 2000a). Inspired from folklore, epic poetry and national (pseudo)history, these narrative leitmotifs were abundant in political and public speeches, press articles and individual stories "about oneself and others" about "the Serbian nation and its destiny" (Čolović, 2000a, 2000b; Žanić, 2007; Živković, 2011, etc.).

At the beginning of the Milošević-era, the popularization and the diffusion of 'national heroes' often compared or spoke of as the 'embodiments of ancient heroes' from epic poetry and national pseudo-history was largely exploited in the regional ethnological literature (Čolović in case of Serbia, Žanić in case of Serbia etc.) and was the topic of numerous newspaper articles, tv-shows and even comics books (Čolović, 2000a). Taken as 
role-images for the young generations they have obtained a tremendous amount of media attention and support which proportionally declined as one armed conflict went by. During the 90's in former Yugoslavia, and consecutively in Serbia, efforts to sustain in various manners the process of a creation of a nation-state (Banac, 2009) were tainted with fervent nationalism which remained ever since interlinked and are used still in everyday politics in present-day Serbia.

The war-time which was produced by these efforts was such a "sacred time" (Eliade, 1967) when acts of mythic heroes were revoked and were distributed to those individuals which were prepared (eagerly) to enter those "sacred time" when nation/ state building was scheduled.

Exploiting the link between festivity and war on the footsteps of Roger Caillois and George Bataille who drew striking formal correspondences between festivities and war as prominences of excess, the waste, the destruction the flagrant violations of rules, laws and taboos was already done by Mattijs van de Port (1998) who did fieldwork in the city of Novi Sad exactly in that phase of the mediatic glory of Serbian paramilitaries. And although his book mentions these armed paramilitary men who filled those times the restaurants with Gipsy music on those time in Novi Sad, he clearly compares the circumstance of the war to a 'feast' of exuberances of all kind in which "[...] people who in festive moods took the role of the barbarians" (van de Port, 1998: p. 17).

In such 'sacred times' in which no rules were to be respected anymore, the rise of often anti-social (criminal) individuals (Pavičević \& Patić, 2007) willing to assume the role of the "barbarians" who accomplish the bloody job of defending the nation was logical.

Taken from another angle, Živković (Živković, 2011) examines another narrative leitmotif widespread in Serbian public and intellectual life of those years which sustained tremendously the mythical rise of the Serbian paramilitary units members: the rise and fall of the Serbian nation was interpreted by local intellectuals all the long of the 20th century as the struggle between two "spirits", two faces of the Serbian character embodied in its populations according to its natural habitat: the highlanders and the lowlanders. The highlanders being martially-oriented, living in tribal spirit which is genuine and unspoiled by the (à priori corruptible) civilizational influences (of Europe) and the lowlanders who are soft, intellectually (pro Europe) oriented, spoiled by the civilization and having a rayah $^{2}$ - (servant) mentality (Živković, 2011). Of course, the members of the numerous Serbian paramilitary units fit exactly to that imaginary un-submissive mentality of the highlander hajduk ${ }^{3}$ (Bougarel, 1999).

While they fit perfectly to play a bloody role of the "sacred times" of wartime, why were they than discarded in peacetime?

\section{Times of Glory}

In an article of the first edition of his marvelous book "The politics of symbols" (1997) while analyzing the metamorphosis of football fans into warriors - volunteers of the armed conflicts which raged during the 90's on the territories of former Yugoslavia, Ivan Čolović (Čolović, 2000a) predicted the victory of the "hooligan-tribes" and the creation of a new "vandal-warrior aristocracy". This book, among others, was translated to several

\footnotetext{
${ }^{2}$ Turkish.

${ }^{3}$ Outlaws in the Balkans during the Ottoman period.
}

languages and was well received by the public interested in the tumultuous Balkans of the 90's. The years that followed the publication of that book proved that Colović was right: the "vandal-warrior aristocracy" forged in the cycles of war during the first half of the 90's reigned the Serbian medias, the tabloids, the so called "jet-set" of the major cities.

Such a metamorphosis of football fans into paramilitary "soldiers" described by Čolović in that book is a known phenomenon analyzed for its relation with genocide (Alvarez, 2006: p. 14). The young, mainly unemployed sport zealots transformed into "fervent patriots" ready to kill for "higher purpose" are unfortunately one of the main vectors, a "perfect tool" for genocide and ethnic cleansing (as f.i. in the case of the Interhamwe in Rwanda). In Serbia's case Arkan and his unit called the "Tigers" is the best known example. This paramilitary unit was composed from football hooligans and football fans "transformed" almost overnight into professional soldiers, and later constituted the hard-core of several other paramilitary units.

The "warrior aristocracy" was omnipresent in public life, establishing a social tendency in looks, behaving, ruling in every manner with the help of the media of Serbian society. The leaders of different Serbian paramilitary units had the status of public figures and were the center of the public curiosity. Stories, anecdotes about their "glorious" past during the wars (1991-1995) and especially their after war lifestyles were published in tabloids with a wide circulation. Biographies of the paramilitary leaders were published and sold out in bookstores. Some of the leaders were regular guests in television broadcasts with a status similar of a pop-celebrity (Čolović, 2000a; Vivod, 2009). The public was keen of all possible information about them: what car do they drove, what clothes do they wore, where they vacationed, etc. They represented an image of success, and figures looked upon by the youth ${ }^{4}$. Money, political connections and the nimbus of loyalty to "serbianhood" followed them.

And then, just before of the fall of the Milošević regime (October 2000) - one main paramilitary figure, the leader of the "Tigers" Arkan was assassinated (January 2000). A couple of other known paramilitary leaders, mafia bosses, were assassinated also in a short period of time ${ }^{6}$. Those who did survive were shifted from the center of the public attention: less and less information about them reached the public.

After the fall of the Milošević regime, while the new gov-

\footnotetext{
${ }^{4}$ Commenting about the popularity of the paramilitary leaders during the $90 \mathrm{es}$, an interlocutor of mine (at the time he was in his mid 20es) stated referring to the popularity of Arkan and his folk singer wife: "Fxx the country where the ideals of the youth are a murderer and a prostitute." [" $J x x$ zemlju u kojoj su idoli omladine ubica i k...a"]. (the swear-words are marked with "x").

5“serbianhood" or srpstvo in Serbian language is a concept based on ethnic unity and ethnical belonging and orthodox Christianism; perceived as a unity having the same characteristics as an individual: f.i. behave, have rights, and even bleed as an individual (f.i. see Dučić, Jovan. (1871-1943) poet, writer and diplomat.in Verujem u boga i u srpstvo (I belive in god and in serbianhood), Centralni Odbor Srpske Narodne Odbrane u Americi, Cikago 1942, page $18,22,23$

${ }^{6}$ f.i. in March 2000 Branislav Lainović — a mafia boss from Novi Sad—who was also the right hand of Djordje Božović Giška the leader of the paramilitary unit "Serbian Guard"-Srpska Garda) and several other individuals linked with organized crime as f.i. in February 2000 Mirko Tomić aka Bosanac and twelve days later Radosav Trlajić aka Bata Traja; Interestingly Yugoslavia's (at that time the name of the country is Federal Republic of Yugoslavia constituted from the federation of Serbia and Montenegro) defense minister Pavle Bulatović was assassinated also during this troubled month of February $2000 \ldots$
} 
ernment was working on reforms, there was another topic which hit the main news of the Serbian media and which was related to the Serbian units employed in one of the series of armed conflict in territories of former Yugoslavia. One of the so called "special units" the Red Berets (Jedinica za specijalne operacije-JSO) had begun a strike which had all the appearance of a military coup ${ }^{7}$. JSO was another paramilitary unit ${ }^{8}$ which was almost unknown to the public during the 90's, organized by the Serbian Service of State Security. This military coup was later linked with an event which transformed the majority of the Serbian public opinion about the paramilitary units: the assassination of Prime Minister Đinđić in March 2003. Following this event, the Serbian state declared war against the organized crime groups and it was a moment when the criminal past of the paramilitary troops and their leaders came in the center of public concern. As it turned out, some leading members of the Red Beret unit were closely linked to an organized crime group. They were accused and later sentenced (2005) for the assassination of the PM Đinđić.

The years which followed after this assassination, Serbian media reported several accusations, trials for committing war crimes of several paramilitary leaders and unit members (the Scorpios, the White Eagles, the Yellow Wasps, etc.). Video tapes, testimonies of survivors and victims resurfaced in the media - especially in independent media, the state media being heavily under the influence of the nationalist political currents. The time of glorification of these units and their leaders seemed to belong to the past - at least publically.

Analyzing the past two decades, two main phases emerge of the public image and representation of the members and the leaders of the Serbian paramilitary units. In the first phase these "volunteers" were depicted as the heroes and the protectors of the Serbian nation in danger in its ancestral territories. Compared to the epic champions from traditional epic songs, history myths and legends they were represented as almost saints battling for the greater cause: for the nation, for the ones who were incapable to fight for themselves - women, children, elderlyand the protectors of Christianity (Čolović, 2000a; Vivod, 2010).

Although the glamorous lifestyle they led during the series of incessant conflicts spread rumors in Serbia-in their "Matrix"of looting and other criminal activities in the war ravaged territories, the "fighters", combatants of the paramilitary units were represented in the Serbian media as mainly "volunteers" who went to the war-ravaged former territories of Yugoslavia to protect the Serbian "fellow countrymen" for no pecuniary reason at all. The fact that some convicted criminals were 'drafted' in such units, and that several paramilitary leaders were mafia bosses also added even more truth to the rumors which reached Serbia. Speaking about the prior criminal "carrier" of the leaders and unit members Čolović (2000) stated that the criminal past of these leaders made them "more convenient" for the task of protecting the nation, indicating a "parabola of the sinful son" ("parabola o bludnom sinu") and referring to this prior

\footnotetext{
${ }^{7}$ See final word of Attorney Srdja Popović in the case Serbian state vs Milorada Ulemek et al., Belgrade District Court, 24th of April 2007.

${ }^{8}$ Although the JSO apparently was an armed unit which had all the appearances (affiliation, armament, command chain, etc.) of special army or police force, the author of this article opted to add them to group of "common armed individual" (see infra) for two main raisons: the core of this unit were from the Arkan's Tigers and Captain Dragan's Kninjas; secondly this unit continued to recruit (after 1996) in the same manner as the several paramilitary units at the beginning of the 90 es: using f.i. small adds...
}

criminal past as the "sins of a youth" (Čolović, 2000: p. 181)

Nevertheless, the open talk about their misdeeds and criminal activities of looting, genocide, war crimes and rape were printed in the headlines of newspapers or reported by television channels only after the fall of the Milošević. Although there was almost no open public debate in any form about their role in war crimes, genocide committed or the support of these troops by the Serbian (during Milošević) government, and since the fall of the regime small efforts have been made to reveal the past of these units, the chat rooms, blogs on internet were (and remain) the battle field of the supporters, the fans of these "heroes of the nation" and the ones who are convinced that the troops were the main vector, the tool of the ethnic cleansing, the genocide in the former territories of the late Yugoslavia. For the first group these veterans remain popular, untouchable and their reputation uncontested: the mission of these units was the protection of "serbianhood" and for the sake of this mission the members of these units were and remain untouchables.

For the second group they are the source of all evil behind what happened during the armed conflicts of the decomposition of the country. After the fall of the Milosevic-regime negative events which shocked the Serbian public are explained, interpreted - especially by the independent media - in the perspective of this very dubious past, as an unwanted "heritage" left by these units. The origins of the contemporary events are investigated through the looking glass of the ideology of the past which instigated the formation of such units, the motivation of the paramilitaries to act as they did, and consecutively the admiration of the Serbian public mirrored in mediatic cover they enjoyed. After a decade of the overthrow of the Milosevic regime, these units and their former members are the embodiment of the link between the past and the present.

I argue that at present we are witnessing a third phase of the public image of these veterans: the current, especially the negative events are interpreted à posteriori in the light of not so "glorious" past, which is more and more reviled publically. The myth of these "warriors", "heroes and protectors of the nation" and their leaders linger on in the present, suffering a radical alteration: from being the protectors and mythical heroes they become the quintessence of violent behavior and intolerance, the residuum of the nationalist regime. What was at the time of Milošević reign a "virtue", a socially accepted and well seen behavior is at present finger-pointed, analyzed as a social pathology.

The explanation offered through the independent media claims that the roots of newest events are in the military virtue popularized in the past, the ethno myths, the thinking and behaving patterns inherited from this former regime, perpetrated by the paramilitary units and maintained by their contemporary followers (journalist, writers, sportsmen, etc.), with whom the past Tadić-government was unable (or unwilling) to dissociate

\footnotetext{
"Interestingly, the "sins of a youth" can be "washed" by the activity in a paramilitary unit: At the celebration of the $8^{\text {th }}$ anniversary (in August 1999) of the founding of the paramilitary unit Serbian Guard (Srpska Garda) Jovan Otašević gave an interview to the Serbian daily Glas Javnosti (The Voice of the Public) stating that bishop Atanasije of the Serbian Orthodox Church declared that Djordje Božović aka Giška (the leader of this unit who was shot and killed in Croatia in 1991) washed his earlier sins with his subsequent activities (the ones committed in Croatia?) off. "Giška je grešio kao mladić. Ali, znate, postoje stvari koje biste uradili kao devetnaestogodišnjak, ali ne i kao zreo čovek od trideset pet. Ali, kako kaže Vladika Atanasije, ako je i učinio nešto loše u životu, on se kasnije potpuno oprao." http://arhiva.glas-javnosti.rs/arhiva/1999/08/02/srpski/R99080102.shtm
} 
itself and the present Nikolić-government is closely linked ${ }^{10}$. A link between the present and the past which is actively created in this manner in the Serbian media, reveals the belief that the wrongdoings made in past still reverberate in the present, following the Serbian nation as an obsessive compulsive behavior which prevent the modernization, the "Europeanization".

As the events, such as war crimes and genocide, are discovered and revealed every day, the conviction that present society can't, but yet again, must face the past is growing. In this line of thinking the paramilitary units represent the quintessence of the shady past that the divided public of present has to discover and to face.

In order to scrutinize this argument it would be preferable to mention some facts about the Serbian paramilitary troops engaged during the wars in former Yugoslavia:

There were a surprisingly huge number or paramilitary formations during the wars in former Yugoslavia (1991-1999) from which several - the most notorious ones were the subject of many studies or mentioned as the main vectors of committed war crimes and genocide (Alvarez, 2007; Duffy \& Lindstrom 2006; Judah, 1997, etc.). The shocking amount of unities, particularly employed by the Serbian forces pointed toward as if every region had its own paramilitary unit which was employed parallel to the official army in certain period of time.

The United Nations Security Council ${ }^{11}$ reported in 1994, that in the conflicts on the territories of the Republic of Bosnia and Herzegovina $(\mathrm{BiH})$, the Republic of Croatia, and to a lesser extent, the Federal Republic of Yugoslavia, 82 "paramilitary organizations" $" 12$ were employed.

Under the definition of the UN Security Council the:

Paramilitary organizations exist in several forms. Some are highly-organized groups and operate in several theatres in conjunction with regular military formations. Others are loosely organized and act alone in a single village or on an ad hoc basis. Some of the groups preceded the conflict, others followed it. Still others were formed as the need arose during the conflict. These groups have been organized by the governments or militaries of the warring factions, by political parties, as well as by local police, political, military or community leaders. The members of these paramilitary organizations have been drawn from the regular army, Territorial Defence forces, local militia and police, local civilians, expatriates, and foreign nationals. According to some reports, the paramilitary organizations also include criminals released from prison solely for the purpose of forming these units. $^{13}$

The paramilitary forces operating in the territory of the former Yugoslavia were classified into four categories: Special Forces, "Militias", "Paramilitary units", and "police augmented by armed civilians".

Fabian Virchow (Virchow, 2007), although he refers to the U.S. militia movements, gives a simple two-word-definition of the term militia which covers well the semantic field of the majority of the paramilitary units employed during the conflict in former Yugoslavia and which are particularly interesting for

\footnotetext{
${ }^{10}$ According to some information published in the media (source B92): Nikolić himself was at time a member of a paramilitary unit (White Eagles under the sponsorship of the Serbian Radical party which leader faces trial at the ICTY in The Hague).

${ }^{11} 28$ December 1994 "Final report of the United Nations Commission of Experts established pursuant to Security Council resolution 780 (1992)" (S/1994/674/Add.2 (Vol. I Annex III.A).

12 idem.

${ }^{13}$ Idem.
}

me: armed "citizenry".

In my fieldwork I was interested in the members of Serbian paramilitary units which can be put in the last category as "armed citizens", more correctly, armed s.c. "common individuals" or "actors" of normal situation in a a-normal situation such as the war, the ones "from segments of a society that are extremely vulnerable to indoctrination into ideologies and practices of violence" (Alvarez, 2006: p. 26).

Fifty five paramilitary groups were operational in support of the Government of Serbia, 13 of Croatia, and 14 were Bosnian Muslim paramilitary units. The Serbian groups were known under various names: several had very "picturesque" namespossibly describing their battle-ideals - such as: the Tigers, the Scorpions, the Panthers, the Wolfs, etc.- the names of "animal predators" (Čolović, 2000a). Others groups used the names of their leader (f.i. Jovićevci-the Jović-group, Dragina Grupathe group of Drago) or employed a name a geographical topos indicating their origins (f.i. Bilogoroski Odred-The division from Bilogorje, Knindže- -Ninja-s from Knin"), or names inspired from history (Armada, Četnici, Dušan silni, Garda) (Čolović, 2000a. UN report 28. 12.1994). These scenic names reflect a hidden message, an ideology which inspired these units: for instance the ones inspired from toponymes claimed spatial attachment, or those using a "historical" name aimed to maintain a temporal continuity.

The criteria which lead the UN officials to organize the paramilitaries was the actual support which the units got from their "Matrix" (Yugoslavia for the Serb forces, Croatia for the Croats, Bosnia for the Bosnians). The support was in money (in form of salaries), armament and other equipment, such as the vehicles, uniforms, fuel, back up, training bases, and volunteers (Alvarez, 2006; Andreas, 2004; Glaurdic, 2009: p. $97^{14}$ ).

The members of these units were recruited in two manners: informally - through publicity (via the medias, newspaper ads (Čolović, 2000a), personal contact, friendship, family ties (see testimonies of Scorpions) or formally-f.i. through party membership ${ }^{15}$, organized sport supporters clubs, or drafted

\footnotetext{
${ }^{14}$ Interestingly in the interview of Der Spiegel with Siniša Vučinić the leader of the Serbian Hawks (Srpski Sokoli) paramilitary unit he states that his units is entirely financed from abroad, from the Serbian emigrants (Spiegel 41/1992: 201b) although he adds later that his unit maintain contacts with the regular army (JNA) which "leaves [them] a lot of heavy armament" ... Source of the whole interview in Serbian language: http://www.pescanik.net/content/view/3803/65/

${ }^{15}$ Several Serbian political parties had "their own" paramilitary units which were organized, entrained and financed through them. For instance the Serbian Guard (Srspka Garda) was a unit organized by the Serbian Renewal Movement (Srpski Pokret Obnove-SPO) with Vuk Drašković as a political leader (Source: transcript statement: Witness VS-2000 page N14105 (resumes) (open session). Cross examination by Mr Seselj; IT-03-67: Seselj[DOC] Public Transcript of Hearing 05 February 2009 (English, 99 Pages) Document Type: Transcript. Date: 05/02/2009. By: Trial Chamber III); Siniša Vučinić the president of the Royalist Movement (Rojalistički pokret) was also the leader of the paramilitary units the Serbian Eagles (Srpski Orlovi) (see Spiegel 41/1992); the Serbian Radical Party (Srpska Radikalna Stranka-SRS) with Vojislav Šešelj (at present on trial for alleged war crimes and possible crimes against humanity by the International Criminal Tribunal for the former Yugoslavia (ICTY) organized the White Eagles (Beli Orlovi) although Vojislav Šešelj denied his association with this formation: "In previous wars (Bosnia, Croatia) there was a small paramilitary organisation called White Eagles, but the Serb Radical Party had absolutely nothing to do with them.” Testimony of Vojislav Šešelj, Transcript of 23 August 2005, p. 43081, lines 16-18. Nevertheless see: the testimony of the witness VS 1055, a protected witness in the trial of Vojislav Šešelj and see the interview with Siniša Vučinić (a self proclaimed "duke" of the Chetnik Movement), Der Spiegel. 41/1992 201b. author Renate Flottau, among many other documents, and testimonies stating the contradictory.
} 
under command - in case of several professional soldiers who were charged to lead, entrain the groups or simply to "lift up the professional level" of a unity (see testimony of protected wit- ness K-2 at the Trial of Slobodan Milošević at ICTY).

The groups were constituted from men of different ages, social classes and professional backgrounds. There were originnated from: the territories under the conflict (as they like to emphasize "they defended their village, their properties and families") such as Croatia, Bosnia and Herzegovina, from Serbia (Spiegel 41/1992, testimonies of former Scorpio unit members) - a country which "officially" was never at war, a statement which was propagated through the machinery of the Milošević regime (Biserko, 1999; Hartmann, 2002) and expatriates - first or second generation of Serbian citizens from abroad $^{16}$

After the series of armed conflicts (1991-1999) the former members of paramilitary units were dispersed. Some returned to the territories in which they fought (or rather stayed on the conflicted territories - being originally from there). A great part went to stay in Serbia. There were several reasons for such a migration: one of it was to reunite with their family members who came as refugees during the conflicts, some of them because they had investments on the Serbian territory (f.i. they purchased a property in a form of house, firm, etc.). Many of them actually were originally from Serbia (Spiegel 41/1992). A reason for this relocation was also a fear of retribution: they felt unsecure, that they will be recognized and indicted as war criminals (Vivod, 2009).

In the countries of the former federation - at the time the "enemy"- the names of these units match with "genocide", "war crimes". After the conflict, several former Serbian paramilitaries were indicted and sentenced as war criminals in local special tribunals (in case of Serbia and $\mathrm{BiH}$, in case of Croatia the local, the županijski (district) tribunals were reinforced to be able to handle the cases of war crimes), other were accused and condemned in Hague by the International Criminal Tribunal for the Former Yugoslavia (ICTY).

Having the benefit of access to the "great Pantheon" of the local Medias during the 90's, they were presented in Serbia as the stars, war heroes, the guardians, the defenders of the Serbian people and its territories (Čolović, 2000; Jansen, 2000). The leading personalities of these troops were present as public figures in the political and in cultural life during the 90's as f.i. the notorious Ražnatović aka Arkan, Dragan Vasiljević aka Captain Dragan, and others (idem).

For instance, taking the example of the broadcaster Pink, with headquarters in Belgrade which broadcasts nationwide, who had a couple of TV shows in which Arkan (the leader of the Tigers) and his folk singer wife Ceca were regular guest (f.i. in the shows of Milovan Ilić-Minimax) ${ }^{17}$. Captain Dragan (Dragan Vasiljković) $^{18}$ the leader of the Kninjas-Ninja's from

\footnotetext{
${ }^{16}$ Results of fieldwork.

${ }^{17}$ Results of fieldwork.
${ }^{17}$ here is an urban legend which says that during one TV show on the Pink television hosted by Minimax which was imagined as "interactive" (viewers were allowed to call and ask question to the guest in the show), one women called to ask Ceca from where she has the seemingly expensive necklace. The women recognized a custom-made necklace from a relative of hers, which was brutally murdered in the territories under the conflict.

${ }^{18} \mathrm{He}$ is accused by the Republic of Croatia of being responsible for soldiers under his command allegedly torturing, beating and killing captured members of Croatian Army and Police in 1991 in Knin. On 12 April 2007, authorities in Sydney granted Croatia's extradition request. On 3 February 2009 Vasiljković appeal against extradition to Croatia was rejected by the Federal Court of Australia.
}

Knin (Knindže) was impersonated as main figures in a serial of comic books bearing his name (Čolović, 2000a). A silver coin was minted with his image. With one side stating that "Terrorism stops here" and the other side bearing the inscription of "Captain Dragan Fund" (Fond Kapetana Dragana) created in order to help wounded patriots and families of those who died at the front. Djordje Božović aka Giška, the leader of the Serbian Guard (Srpska Garda), a paramilitary unit initiated by the Serbian Renewal Party (Srpski Pokret Obnove), was a topic of numerous publications-books, articles and documentaries, as other paramilitary leaders too ${ }^{19}$ - as criminal who was converted into a national hero defending the "Serbian cause".

Most of these formations were dissolved after the conflicts, and the great part of the Serbian paramilitary leaders died after the conflicts - and not from natural causes - only a few remained more or less "active" during the peacetime, particularly after the fall of the Milošević's regime in 2000. Two examples are the Red Berets (Crvene Beretke) or JSO (Jedinica za Specijalne Operacije) the Special Operations Units. The leader of this unity Milorad Ulemek-Luković aka Legija, along with a couple of his subordinates, were sentenced to 40 years prison for the murder of the Serbian Prime Minister Zoran Đinđić in 2003 (supra).

Although there were rumors in Serbia-the Matrix of these units - about the lootings, murders and rape committed by these units during the 90's, the criminal past of the paramilitary units reached the public in Serbia through the Serbian media only after the fall of the regime (2000). The most shocking evidence of the activities of these units came to the Serbian public via local media when a video tape of the Trnovo/Srebrenica massacre (1995) was broadcasted in 2007 first on B92 Television (the documentary "The Scorpios, a home movie"20). A couple of unit members of the Scorpios murdered, in cold blood, six civilians from whom three were just teenagers. The premeditation of this act is clearly evident when one of the unit members asks seemingly the youngest of them if he ever made love (using a vulgar term). When receiving a negative answer the shooter concluded with "And you won't either". The "Scorpio" members shot these six individuals with bound hands while making jokes, insisting that the cameraman shoot the whole scene of the execution, delaying the last execution to make sure that the camera's battery isn't empty.

The phase of the glorified image perpetuated in the Serbian Medias during the 90's was over. A special tribunal in Belgrade was made in order to put on trial the individuals who committed war crimes. The IC Tribunal for the FY in Hague has indicted and condemned some members of a couple of Serbian paramilitary units (f.i. White Eagles - massacre of OvčaraVukovar/Croatia). Some other former paramilitaries were convicted later in Serbia (the Scorpions, the Red Berets-for the massacre in Trnovo, Srebrenica/Bosnia, and the massacre in Podujevo/Kosovo, the Red Berets for the murder of P.M. Đinđić).

The denunciations, the testimonies and the videotapes of cold blooded murders revealed in the Serbian press and the televi-

\footnotetext{
${ }^{19}$ f.i. Marko Lopušina's Commandant Arkan; Vojislav Milić's My son Đorđe Božović Giška and many others.

${ }^{20}$ Documentary first shown in 2007 . Realised with the financial support of National Trust for democracy (NED), USA and the Sweden Helsinky Comitee for Human Rights (SHC), Sweden. The documentary contains archive materials from the of the humanitairian Right (Fonda za humanitarno pravo), the International Criminal Tribunal for the Former Yugoslavia (ICTY) and the materail filmed by the Scorpions themselves.
} 
sion, and the fact that in the case of the "Scorpios" the material was actually filmed by the unit members, added to the notoriety of these units in Serbia. Nevertheless the spotless "glory" of the war heroes is still undisputable for at least a part of the population. Their popularity is detectable by the number of fans of "groups" or web communities on Facebook, or Youtube postings dedicated to these units. For this part of the population made by "enthusiastic" individuals and the extreme right wing organizations very active in public life of the contemporary Serbia (such as the "Cheek"21 [Obraz], the "National Alignment" [Nacionalni Stroj], the "Serbian Gates" [Dveri Sprske], etc) the paramilitary leaders and the units are the undisputable heroes serving the Serbian national interests ${ }^{22}$.

\section{Dogs of the State}

Since the revelations about their past and actual role during the conflicts, the former paramilitaries are going under a less glamorous chapter of their existence. The frustration about the lost wars, the "lost years" (Vivod, 2009) during which they were battling for the Serbian territories ${ }^{23}$, which are continuing to shrink endlessly ${ }^{24}$, the individual and social impoverishment, and the landmark trial of the former Scorpio members (2005$2007)^{25}$ changed the perception of how the former paramilitaries are seen, and how they perceive themselves.

During interviews with the veterans of a militia the main theme is regret and nostalgia toward "the good old times" -when these soldiers where feared and respected in Serbia, and when the media glorified them as the "epical heroes" and "the protectors of the nation" (Vivod, 2009). The frustration for being once venerated as the savior of the nation and being considered and rejected nowadays as war-criminal and war-profiteer is often combined with rage pointed toward those whom believed to be responsible for this transformation. They feel that the Serbian state has abandoned them (Vivod, 2009) ${ }^{26}$.

The veterans of former paramilitary units live better, even now, than the average of Serbian population, although without any (official) financial support from the Serbian state thanks to the financial advantage which they gained during the 90's by starting some private businesses (opening a shop, developing an export-import activity, etc.).

The wages, paid through unofficial channels during the wartime although officially it was denied that these unit members received any financial compensation (see for more in Spiegel $41 / 1992$ ), were at that time considerable ${ }^{27}$. In fact, the salary

\footnotetext{
${ }^{21}$ Cheek is the symbol of honor in the Serbian language f.i. "having no cheek" means that the person has no honor.

${ }^{22}$ F.i. see interview with Boško Obradović the editor in chief of Dveri Srpske (review of the same name movement) Svetlana Lukić and Svetlana Vuković the $24^{\text {th }}$ of March 2005.

http://www.pescanik.net/content/view/1630/61/

23،"The perception by Serb nationalists of their national space tends to have no relation to the actual extent of Serb-held territory: many still believe that territories such as Dalmatia or Macedonia, whose populations are mostly non-Serb and which were not occupied in the recent war, are nevertheless 'Serb lands'." (Hoare, 2006: p. 460).

${ }^{24}$ The declaration of the independence of Kosovo was seen as another loss of territory.

${ }^{25}$ In the case of the Scorpios the trial for the massacre of Podujevo in Kosovo started in 2002 and ended in 2004; for the massacre in Trnovo/Srebrenica in Bosnia they were trialed 2005-2007.

${ }^{26}$ The Movement of Serbian Veterans registered as a political party as an effort to accomplish more rights for a part of a society which claims to be forgotten. A general assembly was to be held the $28^{\text {th }}$ of February 2010.

${ }^{27}$ see testimony of a former Scorpio member in the documentary "Scorpions, a home movie".
}

was so high that is was an additional motivation to join a "unit of volunteers" (at the time used as an allegory of a militia) and "serve the nation". Several militia-leaders in fact, became very rich through the looting of the population from the territories in $\operatorname{war}^{28}$ (Andreas, 2004). They developed a "business" of smuggling of goods across several states (f.i. Ražnatović aka Arkan/Tigers, Slobodan Medić aka Boca/Scorpions ${ }^{29}$ ). The series of armed conflict were a "marvelous" economic opportunity structure for clandestine commerce and made possible for the enemy sides to establish cross-border smuggling channels (Andreas, 2004). The Serbian press speculates about the total estimation of property of the leader of the Red Berets (JSO) Luković aka Legija, which would be between fifty and one million euro ${ }^{30}$.

And almost a decade after the fall of the regime, a new law went into effect in Serbia (March 2009) which provides under estimations an extra income for the Government for 100 million Euro: every property which is gained though crime and other criminal activities will be confiscated. The list of 300 Serbian citizens contains also the names of several paramilitary unit leaders as well ${ }^{31}$.

The state media, and those who are close to right wing political parties provide a minimum of information about the trials of former paramilitary unit members and their crimes. When it comes to their role that they actually had in the armed conflicts in Croatia, Bosnia and Kosovo and their financing, a certain "taboo" is lifted, especially in the independent media (f.i. B92, Vreme, etc.). The NGO's are those who are organizing a public debate and speaking, and openly spreading information about the crimes of the Serbian paramilitary units (f.i. Humanitarian Law Center from Belgrade, Women in Black, etc.). Very often it is the private media close to a right wing political party or the former ruling party of Milošević (f.i. the TV broadcasters Most, or Palma) who are tacitly maintaining the status they had during the 90's of these units by omitting to report about the trials. It is their past which is still under the discussion, their present, as for instance where are the remaining members now, how the invalids live, what happened to those who are accused of war crimes, etc. is not a topic of the reports.

The media covers meagerly the news about the so called "the veterans of the Kosovo war" who engage a strike (in summer, autumn 2009, winter 2010), blocking the main roads and railway in the region of their origins - mainly in central Serbia, rarely at the capital city of Belgrade-reclaiming their unpaid wages which the Serbian government owes them. The medias report about 2000 law suits are ongoing against the government for the unpaid wages in amount between 600 to 1400 Euro. Interestingly the category of "war veterans" remains vague, it is

\footnotetext{
${ }^{28}$ See statement of General Manojlo Milovanović head of the Republika Srpska Army-VRS in documentary of Filip Švarm Jedinica (The Unit) 2006. ${ }^{29}$ See testimonies of General Manojlo Milovanović head of the Republika Srpska Army-VRS in documentary of Filip Švarm Jedinica (The Unit) 2006 and the the interview Der Speigel with Sinisa Vucinic.

${ }^{30} \mathrm{http} / /$ www.novosti.rs/code/navigate.php? Id=9\&status=jedna\&vest=14745 $3 \&$ title_add $=$ Legija- $\% 20$ nelegalno $\% 20 \% 3 \mathrm{Cbr} \% 2 \mathrm{~F} \% 3$ Esupruga- $\% 20$ po $\% \mathrm{C} 5$ $\%$ A1teno\&kword add=legija $\% 2 \mathrm{C} \% 20$ oduzimanje $\% 20$ imovine http://www.b92.net/info/vesti/index.php?yyyy=2009\&mm=04\&dd=23\&nav category $=120 \&$ nav id $=356980$

http://www.slobodnaevropa.org/content/article/1744465.html

${ }^{31}$ http://www.b92.net/info/vesti/index.php?yyyy=2009\&mm $=03 \& \mathrm{dd}=01 \&$ na v_id=347582

http://www.naslovi.net/2009-09-03/b92/imovina-osumnjicenih-na-proveri/13 06927
} 
uncertain if this term covers the individuals who were drafted in the regular army or it is mixture between the so called "volunteers" and the ones who were conscripts in the regular army ${ }^{32}$. The statements made in the press by the newly registered political party of veterans points toward the second possibility ${ }^{33}$.

The actual Serbian public have a lot of difficulties to face from the past, the deadly 90 ' $\mathrm{s}^{34}$, especially when it comes to the war crimes committed by the paramilitary troops in the name of the Serbian people and the Serbian nation. While grasping, trying to understand the degree of the involvement of these units in series of armed conflicts, the contemporary events are discussed, interpreted in the light of past ideologies which lead to the creation of these paramilitary units, the manner how they acted and in the shadow of the acts they committed in the name of the nation.

Using the independent media and the internet, journalists, writers and thinkers are seeking the roots of unsocial, negative behavior in the military in the military virtues nurtured by the Serbian society during its history, heroic myths, national political ethnomyths perpetrated in public speeches, through the medias during the past twenty years.

Incidents as for instance the demonstrations turned into hooligan disorder and looting (f.i. the demonstration in February 2008 when the independence of Kosovo was declared), an excessive and violent behavior toward the foreigners ${ }^{35}$, the general xenophobia, acts often committed in the name of "patriotism" are serving as a à posteriori explanation of the events from the past decade. Links are made between the past ideals of a Great Serbia, especially the military ideals which nurtured the men which were between their twenties and forties at the time, and who were ready "to serve the nation" during the 90's, and even to die for it, who used this pretext to commit terrible crimes, and between today's youth which aspires to the same military virtues, but this time "at home", on their "native soil" where the aggressive conduct, the murdering and looting continues. It is seen as the same conflict, at present, interpreted as a social problem only relocated in time and space by a new generation of perpetrators. Violent behavior carried out in the name of "greater good", in the name of "family values" and "patriotism" by individuals, football fans or extreme right wing organizations is directly linked with those "values"-now declared as non-values - from the past, embodied perfectly in paramilitary units and its members.

Other events, which shocked the Serbian public such as the

\footnotetext{
${ }^{32}$ One of my interviewed person picturesquely explained this situation that "the state won't feed its dogs who were sent to kill for it".

${ }^{33} \mathrm{http}: / /$ www.rtv.rs/sr_lat/politika/partija-veterana-protiv-martona--lsv-se-za li-mup-u 141175.html The president of the In August 2009 the president of the assembly of the city of Zrenjanin was accused by the Party of Veterans for "extremism and disrespect of the Serbian veterans and of the Serbian state" for receiving in his office the representatives of the Croat Society of lawyers "Vukovar 1991" and supported their idea of raising a monument in two villages where they were held as war prisoners in detainee camps.

${ }^{34}$ For instance the song of a prominent Serbian singer-songwriter Đorde Balašević, popular in countries of the former Yugoslav federation called "Nineties" expresses the public sentiments toward the "deadly nineties": "Then, the nineties have come, sorrowful and grievous... Phobic... Ordinary bums broke into text- and reading-books... It is too late to panic... We gave a chance for the madness to become official... And now we are like simply surprised..

${ }^{35}$ The Serbian media reported 3 - 4 assaults on foreigners in the capital city of Belgrade during the period of September-October 2009; the media reported that there were no other raisons for these assaults except the fact that these individuals were foreign citizens.
}

scandal of the Crna Reka drug rehabilitation $\operatorname{center}^{36}$, the murder of a young French football supporter in Belgrade by a mob (October 2009) or the cancelation of the Belgrade Gay Pride parade only 24 hours before the event because government officials couldn't ensure public order and the peace and security of the participants (September 2009) are just couple of examples which were decoded by the independent media by taking into account the events of the 90's.

Even the "outfit" of the former Prime Minister Tadic while visiting the maneuvers of the Serbian regular army (October 2009) motivated a journalist ${ }^{37}$ to ask a rhetorical question in the title of his article if "President Tadić is a paramilitary soldier?" (Živkov, 2009) indicating that his taste of clothing may be the sign that his imperatives are far from the values of a demilitarized civil society which he has been chosen to represent.

The political parties in opposition are using the same arguments to criticize the government. The leader of the League of Vojvodina Social Democrats (Liga socijaldemokrata Vojvodine, LSV) a center-left regionalist social democratic political party in Serbia, Nenad Čanak responded on the question why the Serbian authorities remain inactive on the incidents of the extreme right-wing movement:

The police in Serbia, and not only in Serbia, possess always these informal groups which are serving the state with a false identity card. How much paramilitary, under quotations marks, units had we during the 90's which ravaged across Bosnia and Croatia, and then at Kosovo, and even here, so you had as a result a beating up of people who attached posters by unnamed individuals. Afterwards it is determined that all of them have official legitimization and that they were members of the Service of the Serbian State Security. ${ }^{38}$

These events are presented as a prolongation of the war crimes committed in Croatia, Bosnia and Kosovo, committed by the same authors-perpetrators or their spiritual "inheritors" for whom they served as an inspiration. The fact that the present government didn't separate itself from the crimes commit-

\footnotetext{
${ }^{36}$ The Crna Reka scandal came to light after a video was released showing center staff beating one of the center's wards. The magazine Vreme (May 2009) has reported that at a clerical-run rehabilitation centre treating addicts in Crna Reka, patients have been brutally beaten by "caregivers" and therapists and that this practice is a part or a "regular therapy". A video posted on their website shows a patient being beaten with shovels and punched on the face. The centre's representatives told his family that the contract (signed mainly by the patients parents) permitted them to use any form of treatment, including light and "more severe" beatings. Initially, the centre was blessed by the local Serbian Orthodox Bishop, Artemije. Interestingly when this scandal exploded through the Serbian medias in public, the extreme right wing organization Obraz organized a support rally for the priest who runs the center.

In a interview (June 2009) I had with a journalist who interviewed a couple of former patients of this rehabilitation center in Crna Reka stated that he have been told that the employed guardians of this rehabilitation center (described as a dog guarded prison camp) are former members of paramilitary units as for instance Arkan's "Tigers".

${ }^{37}$ Ljubomir Živkov Govor Tekstila 10.10.2009.

http://www.pescanik.net/content/view/3790/1073/

38،"Zašto se u Srbiji žmuri na pretnje i pozive na linč desničarskih organizacija, pokušao je da odgovori predsednik Lige socijaldemokrata Vojvodine Nenad Čanak. "Policija u Srbiji, oduvek, ne samo u Srbiji, uvek ima te neformalne grupe koje služe kao država s lažnom ličnom kartom. Pa koliko smo imali 90-tih godina paravojnih, pod navodnicima, jedinica koje su Harale po Bosni i Hrvatskoj, po Kosovu, pa i ovde, pa ste ovde imali prebijanja ljudi koji su lepili plakate od nekih neimenovanih lica. Posle se ustanovi da svi oni imaju službene legimacije i da su bili u članstvu Službe državne bezbednosti Srbije." Source:

http://www.b92.net/info/vesti/index.php?yyyy=2009\&mm=09\&dd=16\&nav _category $=12 \&$ nav_id $=381665$ translation by the author of this article
} 
ted in support of the former regime is an additional proof, an argument for its opponents that the present political elite and its institutions are in fact quiet supporters of the same great-Serbian warmongering ideology which caused almost a decade of suffering of all kind.

We are witnessing the third "stage" of the public image of paramilitary unit members who made a great step, better said 'fall' from being divinized and represented as the ideals, role models of the Serbian society to become a symbol of all evil of the past. No more heroes, doubted and feared, ignored by the present government, they occupy a marginalized social role. Their characteristic which were their advantage in the past (criminal past, violent, asocial behavior, etc.) appears to be the main ground of today's criticism and transfers the public toward a reinterpretation of the past events. Spatial and temporal continuity is constructed with the events and the actors of the past, as if the civil wars are still raging, putting at present the conflicts on the soil of Serbia, which was spared from war on its territory until $1999^{39}$ when NATO engaged airstrikes against the country.

The warriors, protectors of the weak made from "noble" volunteers, from the group of the so called "simple people" were the incarnation of archetypes (in Jungian sense) battling for a just cause. The story archetypes in a form of epical heroes, which stepped out from the cycles of epical poetry for the defense of Christianity, the "week ones and the unprotected ones" turned into collective shadows (Sandić \& Sandić, 2006). The fact that several of them had a criminal past, made the "sacrifice", to embrace the role of volunteers and "go off" to protect the week ones, even more "noble" and attractive. As if this earlier "sin" was a necessary element toward the "correction" which came through joining such a unit, in order for one to become "righteous" in a Christian sense of the term ${ }^{40}$.

The fact that is has been discovered in the meantime that they abused their power, situation and status of the "protector and heroes" for looting, rape and crimes makes them at present even more hateful. An à posteriori explanation, that these units were made of football hooligans, criminals and that they were organized, supported and financed by the Milošević regime is an appealing explanation, simple by its mechanism. The criminal activity of these units is considered under the previous criminal past of its members, which used the conflict as a continuation of their criminal carrier. The promiscuity maintained by the Milošević regime with the secret services which already used criminals during the Titoist regime to "do the dirty work" (as for instance to eliminate political dissidence at broad ${ }^{41}$ ) is offering an additional explanation why these troops committed so many war crimes and massacres in Croatia, Bosnia and Kosovo. A support to this reasoning is an additional argument of the politicians in opposition, the independent press, the journalists and writers, that the regime financed most of these units and then denied to be involved in any armed conflicts which followed the decomposition of the former Yugoslavia.

As the information about the genocide(s) or "war crimes" is becoming wide spread, finger pointing is evolving toward two

\footnotetext{
${ }^{39}$ Interestingly the word "war" is used by many of the informants only when referring to the period of March to June 1999 while the NATO bombing campaign lasted.

${ }^{40}$ The notion of Christian value of paramilitary soldiers is/was taken very seriously: in the documentary "Škorpioni-Spomenar" (The Scorpions-a home movie) a scene is filmed by a Scorpio-member where an orthodox priest is giving a blessing to the member of this unit

During the armed conflicts in Bosnia Serbia was imagined as a bearer of authentic Christian values, and as a last bastion against Islam (Vivod, 2010).
}

main causes: the blame is put on the Milošević regime and his partisans and secondly, toward the personality of the men who were recruited in a paramilitary unit. There are mainly imagined, pictured as asocial individuals, criminals, unemployed young males - the "residuum of the society" (društveni talogas one of my interlocutors expressed). The responsibility is therefore equally distributed between the former regime and the 'bad nature' of the men who made up these units. In the press articles making the link between the past and present through the speech of Milošević at Gazimestan-Kosovo (in 1989) and the violent behavior of hooligans in Belgrade and the raping military units during the armed conflicts in Croatia and Bosnia are embodying such an opinion in the press in opposition ${ }^{42}$.

The civil, demilitarized society of the sober, present-day Serbia is defended by and personified in journalists, thinkers, layers, writers, the representatives of the "intelligentsia" as they portray themselves. The "sacred times" of war which served for state creating purposes are over. This part of the society is in binary opposition with the class of semi-illiterate, unemployed men of inferior social ranks, as they usually are imagined, who choose to embrace the military virtues in order to become warriors. They are the embodiment of the past, and the past values are in another pole in time, in social class and even in terms of the future when it comes to economical projects of a whole nation. Two sides of this interior dynamics are imagined and represented in opposition such in urban/rural, pro European/pro Russian paradigms - since Russia is very much present as an imaginary bloc standing in opposition of the European Community. These two oppositions are the interior forces of the contemporary society which seemingly keep the whole country as its hostage.

Of course there is a possible deeper, seemingly irrelevant cause which makes this gap between theses strata of the Serbian society even more profound. It is motivated by the mytheme expressing a unity and according which the metonymic representatives of the collective (Jansen, 2000), in this case of the whole serbianhood. In this case the metonymic part is the paramilitary units. They are the "brothers of the same blood" of the entire contemporary Serbian nation, and they gave a "bad name" to the whole nation with their actions in the past ${ }^{43}$. Very

\footnotetext{
${ }^{41}$ Former police inspector Mladen Lojović gave an interview to Naša Borba, from Belgrade April the $20^{\text {th }} 1997$, speaking about Đorđe Božpvić aka Giška a convicted criminal and the leader of the Serbian Volunteer Guard, a paramilitary unit organized by the Serbian Renewal Party (Srpski Pokret Obnove): "Giška was one of the people who in the 80 s had contacts with the State Security forces and carried out their dirty work abroad. He didn't know nor did others that they would become disposable".

http://www.ex-yupress.com/nasaborba/nasaborba13.html

Božidar Spasović gave an interview in the documentary "See you in the obituary" (1995) directed by Janko Baljak based on the book The Crime That Changed Serbia by Alekasandar Knežević and Vojislav Tufegdžić. He stated in the film that he was the chief during nine years of a special unit in charge for abroad "actions" of the Yugoslav State Security and he personally "helped" 120 individuals, "criminals" to go abroad and secured them with falsified passports and documents.

${ }^{42}$ Milošević's made a reference to the possibility of "armed battles", in the future of Serbia's national development; For example: Nikola Samarđžić, Bez nasolva $i$ bez muzike (Without title and without music) 23.09.2009. http://www.pescanik.net/content/view/3706/78/; Ivan Torov, 01.10.2009. Sistemsko Nasilja (Systematic Violence)

http://www.pescanik.net/content/view/3746/80/, etc.

${ }^{43}$ Milošević's made a reference to the possibility of "armed battles", in the future of Serbia's national development. Nikola Samarđžić Bez nasolva i bez muzike (Without title and without music)

http://www.pescanik.net/content/view/3706/78/, Biljana Srbljanović, Kad porastem ubiću kengura (When I grow up I will kill a kangaroo) 02.10.2009. http://www.pescanik.net/content/view/3749/129/etc.
} 
often the substantive "we" ( $\mathrm{mi}$ ) is used abundantly in the articles is expressing the idea of this unity. For the contemporary deadlock in society "they" are the true culprits, for they have committed those acts, those atrocities which discredited the Serbian nation. Furthermore there is a darker shadow which remains almost unmentioned but nevertheless is present in the idea of the failings of nation's "heroes" which brought dishonor to the nation: they didn't actually do the job... the territories were lost. The hopes of a "Great Serbia" melted to nothingness.

Allegations are in "vogue" by a part of the media and political parties in oppositions. Unfortunately there is great lack of desire (or courage?) in Serbia to face the past openly and publically about what happened during the 90's. The elements of two main trials which shackled the public (the members of the Scorpios, and the members of the Red Berets for the murder of PM Đinđić) were presented in the press, mainly in the independent press (f.i. Vreme, B92, etc.). However the details about these units, the number of men who were employed in them, the benefits they enjoyed and especially their crimes remain obscure to a great part of the public. Efforts are made by a couple of NGOs (f.i. Women in Black, the Humanitarian Law Center, the Helsinki Committee of Human Rights in Serbia, etc.) which are publishing books, articles, financing the making of documentaries. Unfortunately their work touches only a handful of individuals.

As the current situation of the former paramilitary units members is an uncovered topic by the media, also the many other Serbian paramilitary units remain unmentioned in public. What happened to these other paramilitary units and their members after the everlasting series of armed conflicts of the 90 's seems to be irrelevant. No serious research (scientific or other-especially initiated by the Serbian government) is made about the exact role that these units played. Their activities remain in obscurity leaving a lot of space for guessing and presumptions. The author of this article is regretting the lack of serious studies and the lack of will to organize more open and public debates which could determine their actual role and activities during the armed conflicts following the decomposition of former Yugoslavia. What is even more regrettable is the inappropriate sentence of the Serbian Supreme Court (Vrhovni Sud) in the case of the Scorpios ${ }^{44}$ which leaves a bitter taste for the victims and those who are willing to face this past. As if there is a general desire to leave this past behind without any further analysis.

What Čolović (2000a) calls "the constellation of narratives", Živković (2011) compares it to "Serbian dreamwork" in which imaginaries are relived, embodied and eternally dreamed. In that ensemble of narrative patterns the imagery about the Serbian paramilitaries has found its place during the 90es. The Serbian paramilitaries as the "heroes and the saviors of the Serbian nation" were replaced by other "heroes" of the nation, heroes in the peacetime. Their mediatic popularity started sky rocketing at the beginning of the 90's and assured them a status of pop stars, an untouchable and guaranteed position in their communities. Lifted up by the medias in the pantheon of serbi-

\footnotetext{
${ }^{44}$ The Belgrade war crimes court sentenced four members of Scorpios unit (April 2007) to a combined 58 years in prison for killing six men (three of them minors) in Trnovo/Srebrenica. This sentence was reduced later (2008) by the Supreme Court of Serbia: one Scorpio member was liberated and sent to a new trial; the sentence of the main accused was reduced from 20 to 15 years of prison.
}

anhood in the "sacred times" of the war when they served their purpose - since only the media can assure such a spotlight and instant glory, they were once in the center of public attention, making seemingly everlasting their invented merits. As the embodiment of the past regime and its ideology, their destiny of "fallen Gods" remains uncertain. In the peace-time they are uncomfortable corpus delicti to the present government of Serbia, in which the process of the nation-sate is completed, and in which Milosevic's political party is partially bleached, restored in power and his protégé is the Minister of Interior. At present they are a suitable topic for those who are seeking the traces of the past regime in contemporary Serbian society. The question remains, will they face an unpunished oblivion and will the Serbian society consecutively risk their resurgence and maybe even a restoration somewhere in the future and will more light be shed on the true nature of those numerous paramilitary units, the identity of those men who belonged to them and the true role they played in the decomposition of the former Yugoslavia, remains very current and pertinent and it is to be answered in the near future not by the whole Serbian society.

\section{REFERENCES}

Alvarez, A. (2006). Militias and genocide. War Crimes, Genocide, \& Crimes against Humanity, 2, 1-33.

Andreas, P. (2004). The clandestine political economy of war and peace in Bosnia. International Studies Quarterly, 48, 29-51. doi:10.1111/i.0020-8833.2004.00290.x

Banac, I. (2009). What happened in the Balkans (or Rather ex-Yugoslavia)? East European Politics and Societies, 23, 461-478. doi: $10.1177 / 0888325409346821$

Biserko, S. (1999). Serbia: Dictatorship, implosion or recovery. Security Dialogue, 30, 289-290. doi:10.1177/0967010699030003006

Belousov et al. (2007). Any port in a storm: Fieldwork difficulties in dangerous and crisis-ridden settings. Qualitative Research, 7, 155175. doi: $10.1177 / 1468794107076019$

Bougarel, X. (1999). The "revenge of the countryside" between sociological reality and nationalist myth. East European Quaterly, 33, 157-175.

Čolović, I. (2000a). Bordel ratnika. Beograd: Biblioteka XX vek.

Čolović, I. (2000a). Politika simbola. Beograd: Biblioteka XX vek.

Delpla, I. (2007). Faits, responsabilités, intelligibilité: Comparer les enquêtes et les rapports sur Srebrenica. Cultures \& Conflits, 65. http://www.conflits.org/index2221.html

Fleming, K. E. (2000). Review essays-Orientalism, the Balkans and Balkan historiography. American Historical Review, 105, 1218-1233. doi: $10.2307 / 2651410$

Gill, H. E. (2004) Finding a middle ground between extremes: Notes on researching transnational crime and violence. Anthropology Matters Journal, 6, 2.

http://www.anthropologymatters.com/journal/2004-2/gill_2004_findi ng.htm

Glaurdic, J. (2009). Inside the Serbian War machine. The Miloševic telephone intercepts, 1991-1992. East European Politics and Societies, 23, 86-104. doi:10.1177/0888325408326788

Duffy, G., \& Lindstrom, N. (2002). Conflicting identities: Solidary incentives in the Serbo-Croatian War. Journal of Peace Research, 39, 69-90. doi:10.1177/0022343302039001004

Gordy, E. D. (1999). The culture of power in Serbia. Nationalism and the destruction of alternatives, University Park, PA: Pen State Press.

Hagan, J. K., \& Ivkovic, S. (2006). War crimes, democracy, and the rule of law in Belgrade, the former Yugoslavia, and beyond. The Annals of the American Academy of Political and Social Science, 605, 129-151. doi:10.1177/0002716206287088

Hartmann, F. (2002). Milošević, la diagonale du fou. Paris: Gallimard. Hoare, M. A. (2006). Slobodan Milošević's place in Serbian history. 
European History Quarterly, 36, 445-462. doi: $10.1177 / 0265691406065446$

Hudson, R. (2003). Songs of Seduction: Popular music and Serbian nationalism patterns of prejudice. Routledge, 37, 157-177.

Jansen, S. (2000). Victims, underdogs and rebels-discursive practices of resistance in Serbian protest. Critique of Anthropology, 20, 393-419. doi:10.1177/0308275X0002000401

Judah, T. (1997). The Serbs: History, myth and the destruction of Yugoslavia. New Haven: Yale University Press.

Klain, E. (1993). Destruction and reparation in groups during the war in Croatia. Group Analysis, 26, 109-118. doi:10.1177/0533316493261011

Kovats-Bernat, C. J. (2002). Negotiating dangerous fields: Pragmatic strategies for fieldwork amid violence and terror. American Anthropologist, 104, 1-15. doi:10.1525/aa.2002.104.1.208

Mac Ginty, R. (2001). Ethno-national conflict and hate crime. American Behavioral Scientist, 45, 639-653. doi:10.1177/00027640121957402

Mylonas, C. (2003). Serbian orthodox fundamentals: The quest for an eternal identity. Budapest: Central European University Press.

Nikolić-Ristanović, V. (1998). War and crime in the former Yugoslavia. In V. Ruggiero, N. South, \& I. Taylor (Eds.), New European criminology (pp. 462-480). London: Routledge.

Picard, M., \& Zinbo, A. (2007). Sur le rapport du gouvernement de la Republika Srpska. Cultures \& Conflits, 65.

http://www.conflits.org/index2242.html

Pavićević, O., \& Simeunović-Patić, B. (2007). Social context and the rise of antiheroes. Facta Universitatis. Philosophy, Sociology and Psychology, 6, 53-66.

Van de Port, M. (1998). Gypsies, wars and other instances of the wild: Civilization and its discontents in a Serbian town. Amsterdam: Amsterdam University Press.
Van de Port, M. (1999). "It takes a Serb to know a Serb"-Uncovering the roots of obstinate otherness in Serbia. Critique of Anthropology, 19, 7-30. doi:10.1177/0308275X9901900104

Sandic, M., \& Sandic, A. (2006). The archetypes echoed in the collective unconscious of the people. Group Analysis, 39, 411-420. doi: $10.1177 / 0533316406066608$

Scheper-Hughes, N. (2004). Parts unknown: Undercover ethnography of the organ-trafficking underworld. Ethnography, 5, 29-73. doi: $10.1177 / 1466138104041588$

Staub, E. (1999). The roots of evil: Social conditions, culture, personality, and basic human needs. Personality and Social Psychology Review, 3, 179-192. doi:10.1207/s15327957pspr0303_2

Beograd: Fond za Humanitarno Pravo (2007) Škorpioni-od zločina do pravde. Beograd: Edicija: Dokumenta. Publikum.

Flottau, R. (1992). We are going to chop their heads off. Interview with Siniša Vučinić. http://www.pescanik.net/content/view/3803/65/

Virchow, F. (2007). Militia movements. Encyclopedia of Activism and Social Justice. http://sage-ereference.com/activism/Article n560.html

Vivod, M. (2009). Living with dead bodies in your closet-Serbian ex-paramilitary reflections. Anthropology News, 50, 13. doi:10.1111/j.1556-3502.2009.50513.x

Vivod, M. (2010). The story about old hag Europe and healthy maiden Serbia. In J. Fikfak, \& M. Vivod (Eds.), "West" and "East": Dreaming, writing, imagining, and practicing Europe. Ljubljana: Traditiones-Inštitut za slovensko narodopisje.

Volčič, Z. (2005). The notion of the "West" in the Serbian national imaginary. European Journal of Cultural Studies, 8, 155-175. doi: $10.1177 / 1367549405051842$

Žanić, I. (2007). Flag on the mountain: A political anthropology of war in Croatia and Bosnia (566 p.). London: Saqi Books. 